$\begin{array}{ll}\text { Variants } & \begin{array}{l}\text { Variants } \\ \text { The Journal of the European Society for Textual } \\ \text { Scholarship }\end{array}\end{array}$

15-16 | 2021

Textual Scholarship in the Twenty-First Century

\title{
Peter Shillingsburg, Textuality and Knowledge: Essays
}

\section{Barbara Cooke}

\section{OpenEdition}

\section{Journals}

\section{Electronic version}

URL: https://journals.openedition.org/variants/1490

DOI: $10.4000 /$ variants. 1490

ISSN: 1879-6095

\section{Publisher}

European Society for Textual Scholarship

\section{Printed version}

Date of publication: 1 July 2021

Number of pages: 269-271

ISSN: 1573-3084

Electronic reference

Barbara Cooke, "Peter Shillingsburg, Textuality and Knowledge: Essays", Variants [Online], 15-16 | 2021,

Online since 01 July 2021, connection on 16 July 2021. URL: http://journals.openedition.org/variants/ 1490 ; DOI: https://doi.org/10.4000/variants. 1490 
Review of Peter Shillingsburg, Textuality and Knowledge: Essays. University Park (PA): Pennsylvania State University Press, 2017. 240 pp. ISBN: 978-0-271-07850-2.

In "Some Functions of Textual Criticism", Peter Shillingsburg comments the homogenising effect of the poetry anthology. By effacing the social and material contexts in which its poems were first produced, and by reproducing them all "in the same type font with approximately the same margins and spaces between the lines" (60) they belie the individuality of each individual poem. The same observation can be made of an essay collection. The thirteen essays contained in Textuality and Knowledge started life in a number of formats for different audiences, including journal articles ("Textual Criticism, the Humanities, and J.M. Coetzee", 13-27; "Convenient Scholarly Editions", 134-44), conference papers ("Responsibility for Textual Changes in Long-Distance Revisions", 64-82; "Text as Communication", 83-93), and keynote speeches ("The Semiotics of Bibliography", 28-47; "Some Functions of Textual Criticism”, 48-63). According to the book jacket, as collated in a single volume these essays distil "decades of $[\ldots]$ thought on literary history and criticism" from one of the most experienced and well-travelled textual editors in the business.

Some of the texts have been revised, and some melded from more than one earlier iteration for this collection. Were Shillingsburg not a textual editor, it might not occur to a reader to ask exactly where such revisions have been made. However, remarks such as "We have had enough of electronic editions and archives created as look-don't-touch products [...] ultimately abandoned" (192) read differently from the rival viewpoints of 2007, 2010 and 2017. Shillingsburg making this observation in 2007 is a Cassandra; in 2017, he is underlining the overdue need for a sea-change in the ways in which electronic editions are planned, funded and executed. Similarly, the hope that "If we cannot police ourselves, perhaps the public will" as voiced in a pre-Brexit, pre-Trump era now carries a weight of dramatic irony that does not apply if it is, in fact, a contemporary revision. The sociology of critical texts matters as much as that of the literature they critique.

It would be facile to weigh the rival "importance" of such diverse outputs. However, the manner of their grouping can make for uneven reading. Shillings- 
burg's inaugural professorial lecture given at De Montfort University, for example, is directed at a lay audience and argues the case for textual criticism with passion and concision. This eminently accessible piece succeeds "The Semiotics of Bibliography", an involved and detailed argument for the re-evaluation of authorial intention after its almost wholesale disavowal by D.F. McKenzie, reviewing the $20^{\text {th }}$ century history of textual criticism controversies as it goes along. Shillingsburg's view of authorial intent here is closely allied to his Platonic concept of the "work", which runs throughout the collection but is delineated in most detail in "How Literary Works Exist" (115-33).

These theoretical enquiries are applied to case studies in "Some Functions of Textual Criticism" and "Responsibility for Textual Changes in Long-Distance Revisions". In particular, Shillingsburg's discussion (originally presented to an audience at Loyola University Chicago) of a "lost" two-and-a-half pages of To the Lighthouse (1927) cut immediately prior to publication raises multiple questions related to authorial intent. These two-and-a-half pages were, Shillingsburg tells us, cut by Woolf herself. They were not, however, omitted primarily for aesthetic concerns but because the last signature of printed pages was simply too long for the format in which the book was to be bound. That in itself makes Shillingsburg ask whether the longer or the cut version of the text is closer to that Woolf thought best (71). Furthermore, if the cut is accepted, then subsequent editorial difficulties arise from the fact that there are more than one set of "cut" proofs in existence. These are not identical, and carry a number of parallel, smaller emendations. Shillingsburg's enquiry as read here is mostly pragmatic: if one is engaged in producing an eclectic text of To the Lighthouse then which if any of these emendations, large and small, should be adopted - and from which text(s)?

The practical conundrums of this scenario notwithstanding, for literary biographers it is perhaps more revealing as a study in the process of authorial decisionmaking. Authors revise and emend their texts for a whole range of reasons, which might span from "purely aesthetic" to "purely practical" on one axis and "wholly conscious" to "wholly unconscious" on another. Frequently, authors are less precious about the contours of their "work" than their readers and critics: witness Woolf's apparent willingness to cut those two-and-a-half pages for convenience of printing. That is a conscious, pragmatic decision. Less consciously, but equally pragmatically, authors might cut a description short or revise less than usual because they are getting a headache, running low on paper or need to put the bins out. Such decisions leave no trace. Divining "intent" in this network of influences foxes behavioural psychologists, let alone literary critics. Shillingsburg, particularly perhaps the younger Shillingsburg, might tell us it's cowardice not to try. But to those editors inclined to what Shillingsburg characterizes as "critical archiving", that is presenting historically intact versions of text with the minimum of editorial intervention, organising editorial practice around perceived authorial motivation remains a precarious and tangled exercise.

However, there is more at stake in this collection than the (admittedly fraught) 
questions of whether to restore this or that reading, correct that spelling or insert that comma in a critical edition. Throughout the essays, Shillingsburg asks two key questions about the acquisition of knowledge: "where does that come from?" and "how do you know?". These two questions override any in-fighting between specific groups of textual editors, and Shillingsburg deploys them time and again to demonstrate how textual criticism must be the bedrock of the humanities. In "Publishers' Records and the History of Book Production" (178-92), Shillingsburg shows that, as early as 1805, American presidents were denigrating the scourge of "false facts" (191-92). The term finds its corollary in our contemporary battle with "fake news". Shillingsburg's insistence that we insist on the importance of provenance in our classrooms and editions is timely, urgent and — as we would expect — supported by the soundest available textual evidence. 